\title{
Class Voting and the Differential Role of Political Values: Evidence from twelve West-European Countries
}

\author{
Peter Egge Langsæther \\ Department of Political Science, University of Oslo
}

Influential theories of class voting assume that the phenomenon occurs because classes hold different political values, which in turn affect their party preference. However, we do not know how important this mechanism is. Hence, this article uses high quality survey data from twelve Western European countries to study the association between class and voting. The results suggest that political values - including non-economic values - play a central role in accounting for this association, although substantial class differences persist even when holding political values constant. I furthermore argue that the relevance of this mechanism should vary by party family. Political values should account for class voting to the extent that parties give the voters clear signals on issues of relevance to the value orientations. As such, party behaviour not only affects the level of class voting, but the very nature of the link between class and voting. This article contributes first by testing one of the most important theories of the mechanisms behind class voting, and second by demonstrating how the parties' behaviour affects this mechanism. 


\section{Introduction}

Understanding how and why social groups differ in their political preferences and behaviour is of central importance to the understanding of how political systems function. Social scientists have mapped the association between social groups and party preference over time and between countries for a long time, in particular for the class cleavage (e.g. Franklin et al. 1992; Knutsen 2006; Nieuwbeerta 1995). The class cleavage has attracted renewed attention lately, both within and outside of academia, with the election of Donald Trump and the Brexit vote (Evans 2017: 177). The latter is even described as an expression of the democratic class struggle (Evans and Tilley 2017: 201).

Descriptions and explanations of the variations in the macro phenomenon of class voting, both between countries and over time, have often been based on more or less untested ideas about the mechanisms that operate at the micro level: In other words, exactly why belonging to a specific class affects an individual's propensity to vote in a certain way.

This article makes two important contributions. The first is to test in a comparative and systematic fashion one of the most dominant theories about the mechanism behind class voting, namely that class affects political values, which again affect party preference. To what extent do different political values account for class voting? The test employs nuanced measures of several political values based on many indicators. The second contribution is to connect this to the emerging supply side literature, by studying how the intermediate role of political values vary depending on characteristics of the party families. Briefly put, my claim is that political values will only account for class voting to the extent that classes hold different political values, and to the extent that the parties provide clear signals on their stances on issues of relevance to these political values. It follows from this that political values should account for different amounts of class voting for different party families. 
In the following, I first describe the most dominant view on class voting. I then employ supply side perspectives to argue that the role of political values will vary between party families. Third, the article identifies relevant political values, before testing the role of these values in twelve countries. The findings are in line with the theoretical expectations. Finally, implications are discussed.

\section{Class and political values}

\subsection{The theory: Class voting is a question of different political values}

The most important accounts of the relationship between social groups and voting assume that this relationship is due to the social groups' different values. The Michigan school, for instance, theorise that social-structural variables affect social-psychological attributes such as political attitudes and partisan identification, which then affect vote choice (Campbell et al. 1960). This is similar to the view expressed in the seminal work of Lipset and Rokkan (1967), who claimed that social structure affects people's interests and values. This account is also dominant in newer research. Evans and de Graaf (2013: 16), for instance, state that “...the class-party choice association is assumed to be explainable via voters' positions on a dimension of 'economic left-right ideology'." Knutsen (2017: 9) claims that the basic causal model in both 'Inglehart's group polarisation hypothesis and Kitschelt's model (...) can be understood as being focussed on the indirect effect from social structure via value orientations to party choice."

This dominant perspective on the relationship between class and party preference is reflected in the very definition of a cleavage, as stated by Knutsen and Scarbrough (1995: 494). First, a cleavage is based on long-lasting social divisions that create objectively identifiable groups within a society - like classes or religious denominations. Second, the 
members of these groups share a common way of life, giving rise to shared value orientations within the groups. Finally, a cleavage needs to be organizationally institutionalised, for instance in a political party or a church. Class voting, in this view, is based on the fact that classes differ in their political values, which again affects their party preference. While much literature looks at the effect of class on values, there are few empirical tests quantifying the importance of this mechanism relating class and political preferences. Hence the first research question in this article: To what extent do political values account for the association between class and party preference?

\subsection{The behaviour of parties influence the role of political values}

Building on the value model of class voting, the phenomenon requires that classes differ in their political values, but also that these values affect party preference. For this to occur, parties must hold clear positions on issues of relevance to the political values in question. Much research in the emerging supply side literature of cleavage voting argues and demonstrates empirically that the levels of class voting vary with the polarisation and salience of left-right issues in party systems (e.g. Elff 2009; Evans and Tilley 2012; Jansen 2011; Rennwald and Evans 2014, Spies 2013). As Evans and Tilley (2017: 159) put it, "if the parties all offer the same economic policies, why would someone's view on economic policy affect their vote?"

However, not only the strength of class voting, but the very mechanism through which class is associated with party preference, should be affected by party behaviour in much the same way. Class can also have a direct effect on party preference (e.g. Weakliem and Heath 1994: 256), for instance due to group identity, and the degree to which the effect of class is direct or indirect through political values may vary. I argue that political values will account for class voting for a party to the extent that i) classes differ in their political values and ii) 
parties give clear signals on issues of relevance to the political values in question (see also Evans 2017). Parties give signals about their priorities to the voters in a variety of ways. Among two of the most important are the positions they take relative to the other parties in the party system, and the emphasis they put on these positions. Parties in different party families give signals of different strength on different issues, and this gives rise to the second research question in this article, stated as a hypothesis: The intermediate role of political values varies between party families. The next step is to determine which political values that are relevant. Then, I will specify hypotheses for the different political values and different party families.

\subsection{Which political values?}

Values are here defined as 'conceptions of the desirable which are not directly observable but are evident in moral discourse and relevant to the formulation of attitudes' (van Deth and Scarbrough, 1995: 46). To translate unobservable values into an empirically useful device, van Deth and Scarbrough (1995: 41-43; 46) consider attitude patterns that are constrained by values, called value orientations. Which value orientations do class work through to affect party preference?

The classic view is that this is a matter of economic left-right values (Evans and de Graaf 2013: viii, see also Evans 2017: 189-190). Among other factors, the classes' different economic interests (e.g. Goldthorpe and McKnight 2006, Brooks and Svallfors 2010), promotional prospects (Evans 1993) and work conditions (Bengtsson et al. 2013) yield differences in their economic left-right values (e.g. Svallfors 2006, for a brief review see Evans and Tilley 2017: 60). As such, this value orientation must clearly be included.

There have been recent debates on the role of economic left-right values versus more cultural values in relation to Brexit, the election of Donald Trump, and populism (e.g. Hobolt 2016, Inglehart and Norris 2016). A set of non-material or cultural values have also been 
deemed important for class voting (e.g. Houtman 2003, Svallfors 2006, Achterberg and Houtman 2006, Knutsen 2007, Langsæther 2014, Evans 2017, Oesch and Rennwald 2018). Here, I focus on the two cultural value orientations that are directly linked to the rise of the two major, new party families of Western Europe the last few decades, namely the Radical Right and Green parties.

The first is related to immigration. Attitudes to immigration can be considered as basic orientations and have been shown to be "closely related to and reflect basic values and beliefs about different conceptions of national identity, ethnicity and multiculturalism" (Knutsen 2017: 81). Economic competition from immigrants affect workers, in particular unskilled workers, both when it comes to domestic competition from immigrants over jobs, housing, and social services, and due to increased competition internationally from countries with lower labour costs (Betz and Meret 2013: 109-11; Oskarson and Demker 2013: 175; Oesch 2008). The middle class is not negatively affected to the same degree, perhaps not at all, and employers might well benefit from this influx of cheap labour. Not only does the competition over jobs increase due to immigration, but this competition directly and negatively influences the wages of native workers (Bjørnstad 2015). The classes have clear diverging economic interests when it comes to immigration.

Furthermore, the educational differences and occupational experiences of the classes yield differences in levels of tolerance, prevention of scapegoating, and socialisation into specific norms related to avoiding prejudice (Coffé 2013: 138; Ivarsflaten and Stubager 2013: 126, 131; Oesch 2008). The working class typically have stronger national identities and feel more negatively affected by the cultural threat of immigration (Evans and Tilley 2017: 184). For both cultural and economic reasons, then, scholars find class differences in immigration orientations (Dancygier and Walter 2015; Knutsen 2017: 94; Oesch 2008; Oskarson and Demker 2013). 
The other value orientation is environmentalism, which has been described as "the most manifest expression of the 'New Politics' conflict" (Knutsen 2017: 77). The more privileged classes have solved their basic material needs and are free to focus on less fundamental issues than survival (Inglehart 1997). Second, the middle and upper classes are considered to be more politically and socially active, and environmental concern could be seen as an extension of this general concern with social problems. Furthermore, environmental regulations can pose a direct threat to the jobs of industrial workers. On the other hand, lower social strata are in general more exposed to environmental problems, at least local ones (van Liere and Dunlap 1980). Previous empirical work has shown mixed associations between class and environmental concern (Dietz et al. 1998; Gifford and Nilsson 2014; van Liere and Dunlap 1980). To the extent that the classes differ in their environmentalist values, then, these values will account for class voting for party families that hold clear positions on environmental issues.

Knutsen (2017) develops good conceptual and empirical measures for these three value orientations. In this study, I employ these high-quality multiple-indicator measures of economic left-right values, immigration orientations, and environmentalism. See section 4 and the online appendix for more information on the measurement and interrelationship of these value orientations.

\subsection{The Differential Role of Political Values: Hypotheses}

In the analyses, I utilise a modified version of the party family schema of Knutsen (2017), distinguishing between Communist, Left Socialist, Social Democratic, Green, Mainstream Right, and Radical Right parties. For details on this categorisation, see section 4 and the online appendix. 
As discussed above, the general claim of this article is that political values account for class voting to the extent that the classes differ along the value orientation and to the extent that parties signal their stances on issues of relevance to the value orientation in question. The hypothesis that follows is that the class differences in party family preference will be accounted for by value orientations that are important to the party family. Hence, we need to establish which value orientations that are most important for each party family, using a combination of pertinent literature and a measure of signal strength in policy areas related to the three value orientations. This measure is an additive index combining information on the position and salience of different issues for the parties within the party families, taken from the Chapel Hill Expert Survey. The expert survey covers three policy areas directly related to the economy, namely deregulation, redistribution, and spending versus taxation. It furthermore covers a policy area directly related to the environment and immigration. I estimate the signal strength for each party family within each of these areas to find which value orientation the party sends the clearest signals on (see section 4 for more details on the construction of this index).

The Communists and the Left Socialists are the most leftist party families in economic terms (Knutsen 2017: 40-45). They oppose market forces and care about public ownership and a controlled economy (Gallagher et al. 2011: 244-250). Both kinds of parties send out the clearest signals in policy areas related to the economic left-right value orientation. The Communist parties have the strongest signals on redistribution, while the Left Socialist parties send out equally strong signals on redistribution and spending versus taxation.

The centre-left and centre-right parties - the Social Democrats and the Mainstream Right - are in most party systems the dominant parties articulating the traditional industrial economic left-right conflict. The Social Democrats originated as the representatives of workers in the conflict between labour and capital (Lipset and Rokkan 1967) and these parties 
are still the main alternative for left-wing voters in most countries, despite the turn to the centre in the 1990s and the electoral losses in the 2000s (Knutsen 2017: 45). The Mainstream Right, consisting of Conservative, Christian Democratic, and Liberal parties, "oppose the left over state intervention in the economy" (Oesch and Rennwald 2018: 3) and represent the major alternatives to the appeal of social democracy (Gallagher et al. 2011: 260). Both party families give voters the clearest signal in the policy area of spending versus taxation, which is clearly related to the economic left-right value orientation. Based on all this, we can derive the following hypothesis (H1): Economic left-right values account for class differences in support for Communist, Left Socialist, Social Democratic, and Mainstream Right parties.

The Green parties, on the contrary, are not primarily concerned with economic conflicts. They were established in the 1970s and 1980s based on post-materialistic conflicts of values, rather than a materialistic conflict of resources. As the name indicates, they prioritise environmental concern, often at the expense of economic growth or commercial activity (Gallagher 2011: 250-252; Knutsen 2017: 45). They furthermore hold an unambiguous position on the cultural aspects of globalisation, supporting the cultural opening of European societies (Dolezal 2010: 542). Using Benoit and Laver's (2006) expert survey, Ennser (2012: 162) finds that this party family is by far the most environmentalist and immigration friendly in Western Europe. My own measure of signal strength also indicates that the Green parties send out the strongest signals when it comes to environmentalism, followed by immigration. Based on this, I expect that (H2) environmentalism and immigration orientations account for class differences in support for Green parties.

Finally, the Radical Right is also not primarily concerned with economic conflict: "As economics is a secondary issue to the populist radical right, the parties instrumentalise it to pursue their primary ideological agenda, i.e. nativism, authoritarianism, and populism." (Mudde 2007: 145). Oesch and Rennwald (2018: 3) claim that these parties even actively blur 
their socioeconomic positions. On the other hand, these parties are often unequivocal opponents of mass immigration and multiculturalism. It should come as no surprise that these parties send the clearest signal - by far - in the policy area of immigration. I thus expect that (H3) immigration orientations account for class differences in support for Radical Right parties.

\subsection{Data and methodology}

To test these hypotheses, I utilise the latest version of the European Values Study (EVS) at the time of writing, i.e. from 2008-2010. While many sources contain data on occupation and voting intention, this data set is particularly well suited for analysis of political values, as it contains many cross-nationally comparable, high quality indicators that allow us to construct established value indexes with high content validity. In total, I utilise data on 11,266 respondents from twelve West European countries.

The independent variable is class. There are two major alternative ways to operationalise class: the EGP schema (Erikson, Goldthorpe, and Portocarero 1979; Erikson and Goldthorpe 1992: ch. 2), and the newer schema created by Daniel Oesch (2006). While the latter is highly interesting, given its emphasis on newer developments within the middle class, I apply a modified six class EGP schema here (appendix A.2.1). It is still 'the only systematically validated measure of class position available for use in this sort of large scale comparative project' (Evans and De Graaf 2013: 13). Furthermore, recent findings indicate that the criticism against the EGP schema has been somewhat exaggerated, and that the two class schemas have similar explanatory power for party choice (Knutsen and Langsæther 2016, Vestin and Oskarson 2017).

The three value orientations constitute the intermediate variables. These are constructed by creating indexes out of a range of substantial questions about attitudes. 
Knutsen (2017) employed factor analyses to find constrained attitude patterns and I replicate his operationalisation here.

The economic left-right values are measured by asking for the respondent's views on individual versus state responsibility, economic freedom, income inequality versus incentives, private versus public incentives, and views on competition. Immigration orientations are measured by asking how the respondent feels about immigrants. Are they seen as a cultural threat, should they maintain or abandon their customs and traditions, are they a strain on the welfare system or not, and so on. The attitudes the respondent has in these regards are considered to reflect basic values and beliefs about national identity, ethnicity, and multiculturalism (Knutsen 2017: 81). The environmentalist value orientation is measured by asking about views on the relationship between the human species and nature; the consequences of current human economic activity, the willingness to give up income to prevent pollution, etc. These measurements, based on many indicators and thorough content validation, constitute an improvement to studies based on single indicators. In the twelve countries combined, economic left-right values correlate only weakly with environmentalism (pearson's $r=0.12$ ) and with immigration orientations $(r=0.05)$. The latter two also correlate very weakly $(r=0.05)$, indicating that these do constitute separate political value orientations. The exact wording of the questions are in the appendix along with descriptive statistics and the correlations between the value orientations in each individual country.

Party preference is operationalised through a question of vote intention in the EVS and categorised into Communist, Left Socialist, Green, Social Democratic, Mainstream Right, and Radical Right parties. The exact categorisation of these parties is available in the appendix along with descriptive statistics. Parties from Austria, Belgium, Denmark, Finland, France, Germany, Greece, Italy, Luxembourg, the Netherlands, Norway, and Switzerland are included. 
This is a study of the association between class and voting - no background variables are introduced as controls. Comparison between studies is sometimes rendered difficult by the inclusion of a range of different controls without first showing the bivariate relationship, hindering comparison between studies. Some scholars control for intermediate variables, such as left-right self-placement, which supresses the effect of class (e.g. Bengtsson et al. 2014: chap. 9). Other scholars control for variables that are close to, or might be considered to partly constitute, class - such as income or education. On this point, I agree with Oesch (2013: 44), who states that class and education are closely linked. This is because access to several classes depends on successful completion of higher education, while other class positions are very rare among highly educated people.

Furthermore, as mentioned, I have used the Chapel Hill Expert Survey 2010 (Bakker et al. 2015) to create a measure of signal strength to supplement the discussion of the party families in section 3.0. The Chapel Hill Expert Survey 2010 is closest in time to the data collection at the individual level and, crucially, it covers Switzerland and Norway, unlike the 2006 version. The data set includes measures of parties' position and salience of several relevant policy areas. Of relevance to the economic left-right value orientation are measures of parties' position on improving public services versus reducing taxes, whether they oppose or support deregulation of markets, and their position on redistribution from the rich to the poor. There is furthermore a measure of the parties' position on immigration policy, as well as on whether the parties support environmental protection or economic growth. These two cover areas of relevance to the immigration orientations as well as environmentalism. All of these positional measures are accompanied by a measure of the salience of the policy area for the party.

I have coded the parties in the CHES into the same party families as in the EVS data set. In section 2.2, I describe the signal strength as a combination of the deviance of the 
party's position from the mean position in the national party system, as well as the salience of these positions. The signal strength measure used in section 3.0 is simply an additive index of the deviation of the party's position from the mean position in the national party system and the salience of the policy area for the party.

To measure the role of value orientations as an intermediate variable connecting class and voting, we need a measure of the total impact of class on voting, which may be used with and without control variables. The measure also needs to be able to distinguish between different party groups. The traditional measures such as the Alford or Thomsen Index are not suitable, as they require dichotomisation of the party choice variable. I rely on the kappa index developed by Hout et al. (1995), commonly used in studies of cleavage voting (e.g. Jansen 2011; Knutsen 2006; Stubager 2006). This measure is not limited to whether workers vote for left-wing parties, but captures total class voting, the full relationship between a voter's class location and party preference. It is simply the standard deviation of class differences in vote choice.

We can calculate separate kappa values for each voting outcome (Hout et al. 1995: 813), allowing us to study how the importance of value orientations as an intermediate variable varies between party families. The gross kappa (based on a bivariate model) can be compared to the net kappa (based on a multivariate model) to establish how much of the total party group specific class voting that is accounted for by the extra variables - i.e., the value orientations.

In this article, the estimated models are a series of binomial logistic regressions with the dependent variable being voting for a particular party family (e.g. the Social Democrats) versus voting for any other party family. The models include country fixed effects. The kappa value is then simply be the standard deviation of the six class coefficients. The higher the kappa value, the larger the relative class differences in party preference. The gross relative 
kappa from the first model, which includes only class and vote choice, will be compared to the net relative kappas from the other models, which include the value orientation as control variables. This is similar to the logic applied in Tilley (2015) and Evans and Tilley (2017: ch. 8), although they compare predicted probabilities rather than kappa values. The three value orientations will be included one by one to see how much total party group specific class voting they account for individually. Then, in a final model, they will all be included simultaneously to see how much they account for together.

It is natural to expect that the processes leading the classes to obtain certain value orientations and to obtain certain party preferences are similar in the different countries, as they are derived primarily from individuals' positions within labour markets and production units. The analyses thus are based on pooled data from all the countries that have a party from the relevant party family. The major advantage of this approach is that we can include several countries that are unfit for country-specific analyses, as some countries do not have certain combinations of classes preferring certain party groups. This yields empty cells, distorting the results from the logistic regressions.

However, while similar, the processes just described are not likely to be identical across countries. Magnitude differences across countries could arise due to sociological factors related to the classes, or political factors related to the parties. For instance, the regulation of the labour market or the unionisation rate among workers could affect their leftright values. And as already discussed, the parties' polarisation and emphasis of different issues are likely to affect the impact of the values on party preference. Of course, the theoretical point of this article applies also within countries: I would expect class differences of parties within a country to be accounted for by value orientations to the extent that the party differs from other parties in the party system and to the extent that they emphasise these differences. Both sociological and political factors affect how and why the mediation may 
vary by country. While beyond the scope of this study, we need future research to both map and explain cross-country differences in the importance of the value model of class voting.

There are two caveats, both related to the fact that I am using cross-sectional data. First, I cannot ensure that there is no reverse causality. It might be, as Kitschelt and Rehm (2014) suggest, that political values affect the choice of occupation and thus class, rather than the other way around. Second, I cannot ensure that there is any causal relationship at all. Talking about causality is inevitably hard with cross-sectional data, which is why it is the association between class and voting I have attempted to disentangle.

The idea of causality - and the direction of the causality - suggested in this article is based on theoretical reasoning that have been common in the literature at least since Campbell et al.'s (1960) funnel of causality. For modern works based on the same order of causality, see for instance Bengtsson et al. (2013) or Evans and de Graaf (2013). In addition, Brooks and Svallfors (2010: 205) state that their findings suggest "little evidence for the hypothesis of self-selection, in which socialization-induced values dispose individuals to choose jobs (and thus class locations) that are most consonant with their preferences."

\subsection{Results}

The results are presented in figure 1. The first bar in each panel ("class") shows the gross total class voting for each of the party families, when no controls are included. As explained in section 4.1, the kappa is simply the standard deviation of the class coefficients: The higher the value, the larger relative differences between the classes in support for the specific party family. The next bar shows the same measure after controlling for economic left-right values (ECLR). The relative change between this bar and the bar in the class model indicates the amount of class voting that economic left-right values account for. The same applies to the next bars, including the final one, which shows net class voting for each of the party families 
when controlling for all the three value orientations simultaneously.

Figure 1: Party family specific class voting in the different models. Horizontal line at bivariate class voting level from model 1 for ease of comparison.

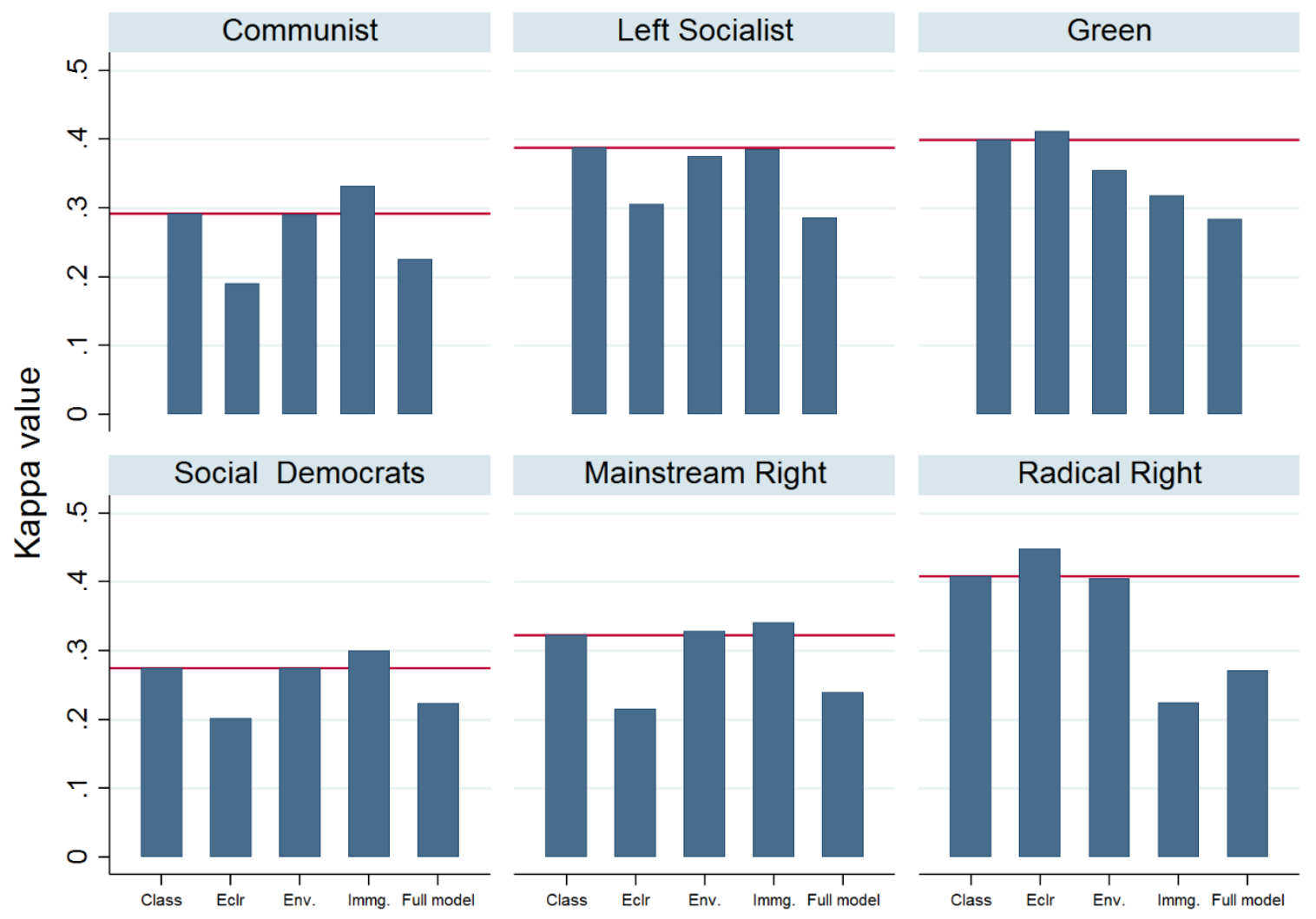

The total class voting, as measured by the gross kappa value, is highest for the Radical Right, the Greens, and the Socialist left, at around 0.40. The class bases discovered for the party families in the data used here are similar to that found in previous research: The high kappa value for the Radical Right is due to the well-established massive overrepresentation of workers and the petite bourgeoisie (see e.g. Ivarsflaten 2005, Oesch and Rennwald 2018), the mirror image of the Green parties' electorate, in which the service classes are overrepresented (see e.g. Dolezal 2010, Oesch 2013). The Left Socialist party family has a very low appeal among the petite bourgeoisie, contributing to the high kappa value (see e.g. Knutsen 2006). The Mainstream Right obtains a kappa value of 0.32 . The higher service class and the petite 
bourgeoisie are both prone to vote for this party family, while workers avoid it. The Communists and Social Democrats have the opposite class basis (e.g. Knutsen 2006, Oesch and Rennwald 2018). There are thus clear class differences for each party family, but the strength of class voting varies between party families.

The first hypothesis is that economic left-right values account for the class differences in support for Communist, Left Socialist, Social Democratic, and Mainstream Right parties. Indeed, this is the case for all these party families. As figure 1 visualises, economic left-right values account for about a third of the Communist and Mainstream Right class voting, and about a quarter of the Social Democratic and Left Socialist class voting. None of the other value orientations matter much for class differences in support for any of these party families. H1 thus receives strong support.

Environmentalism accounts for approximately one tenth of the overrepresentation of the service class and routine non-manual employees in the Green electorate, and the underrepresentation of the petite bourgeoisie and the worker class. Immigration orientations are even more important, accounting for a fifth of the Green class voting. This is more important primarily because class differences in immigration orientations are much larger than class differences in environmentalism. Economic left-right values do not matter. In total, then, the three value orientations account for almost $30 \%$ of Green class voting. $\mathrm{H} 2$ receives strong support.

The final hypothesis is that immigration orientations account for class differences in support for Radical Right parties. Indeed, almost half of the overrepresentation of workers and the petty bourgeoisie is accounted for by immigration orientations. Economic left-right values and environmentalism, on the other hand, do not account for Radical Right class voting. It is perhaps tempting to read this as support for the 'cultural backlash' thesis, which states that support for populism is largely a reaction to progressive cultural change (see Inglehart and 
Norris 2016). However, workers have been opposed to immigration for ages, long before the rise of progressive values (e.g. Lipset 1959) and this is to some extent a direct response to losses workers may experience because of immigration (see Evans and Tilley 2017: 183). To underline this point further, I have re-estimated the models for the Radical Right with controls for age, sex, and education (appendix A.5). Approximately half of the Radical Right class voting is accounted for by these three variables. However, and crucially, immigration orientations still account for $46 \%$ of the remaining class differences when controlling for education. It is thus not obvious that class differences in support for populism or Trump is only the result of cultural backlash.

The value orientations taken together reduce Social Democratic class voting by one fifth and that of the Radical Right with about one third. The value model account for about a quarter of the class voting for the rest of the party families. There can thus be no doubt about the importance of political values as a mechanism connecting class and party preference. However, given the prominence of the idea that class voting is a phenomenon that is indirect through political values, it is noteworthy that less than half of all class voting in fact works this way. We are clearly in need of more research to pinpoint - theoretically as well as empirically - the exact mechanisms through which class affects party preference.

The major theoretical claim of this article receives strong support: Political values account for class voting to the extent that the classes differ along the value orientation and to the extent that parties signal their stances on issues of relevance to the value orientation in question. As such, economic left-right values account for class differences in support for party families that care about taxing versus spending, deregulation of the economy, or redistribution. Immigration orientations account for class differences for party families that emphasise issues related to immigration policies, and environmentalist values account for 
class differences for party families that emphasise issues related to climate change and the environment.

\subsection{Conclusion and implications}

The first contribution of this article is to empirically test and quantify the importance of one of the most dominant theories of how class is associated with party preference. Value orientations surely seem to constitute one of the major mechanisms, accounting for somewhere between a fifth and a third of class voting in Western European democracies. Yet, there is still much class voting that remains unaccounted for. One possible explanation for this is that there may be other important value orientations not included here. Another is simply that political values do not make up the whole story about class voting. There are other strands of literature emphasising identity (e.g. Butler and Stokes 1974), networks (e.g. Huckfeldt 1984, Andersen and Heath 2003), socialisation into partisanship (e.g. Campbell et al. 1960), and perceptions of who the parties represent (Evans and Tilley 2017: ch. 7). This includes not only policy representation, but also personnel, rhetoric, media coverage, and group appeals (Evans and Tilley 2017: 163, Thau 2017; see also Weakliem and Heath 1994). Heath $(2015,2016)$ has shown that the descriptive representation of classes matters for both levels of class voting as well as class non-voting. Voters seem to infer the priorities of the parties not only from their policy positions and the salience of these, but also from e.g. the class background of the candidates. This means that the impact of values could be affected by social representation as well as policy offerings. In any case, it is clear that we need both further theorising of the mechanisms, and more empirical work to establish how much of the class voting that is accounted for by mechanisms pertaining to social networks, material interests, early socialisation, and other factors. 
The findings point us in the right direction when looking for explanations of the variations in class voting over time and between countries. The variations could be due to changes in the effect of class on the political values identified as relevant here; the effect of these political values on party choice; or both.

The second contribution is to study how this varies between party families. Connecting to the emerging supply side literature, I expected variations according to characteristics of the parties. This was indeed the case. Results differ greatly between the party families, and merging these into a Right and Left category in West European, multiparty systems will yield non-valid results. Crucially, the findings indicate that party behaviour not only influences the strength of class voting, but the role of political values as an intermediate variable between class and party preference.

The recent innovations in supply side explanations may also benefit from taking into account the findings of this article. Parties need to offer programmes that differ in respect to the classes' political values if we are to expect class differences in party choice, and 'parties can and do shape class politics by restricting (or accentuating) the responsive voter's choice set along relevant ideological criteria' (Evans and Tilley 2013: 113). But these political values include more than only those pertaining to the traditional economic left-right values. Class voting seems to be the expression of values not only related to the economy, but also to immigration and environmentalism. Supply side studies might thus benefit from including the latter two in their investigations; for example, the increased relevance of immigration issues in most Western European countries could potentially lead to an increase in class voting.

In fact, this is what we might expect given recent developments. The financial crisis and the refugee crisis became important in European countries after the collection of the data used in this article. If the two crises have led to an increased salience of issues related to economic left-right values and immigration orientations among West-European parties, class 
voting may have increased and a larger share of the association between class and party preference may be due to these two value orientations. Future research should test these developments when newer, suitable data is available.

Finally, the framework applied here can easily be used to test other mechanisms. One could study the role of interests by controlling for income, job security or assets and see how much class voting is accounted for, or one could study early socialisation for instance by controlling for the parents' class or education. The framework also works for other cleavages, such as the religious or urban-rural cleavage. In sum, this framework should help with further disentangling the relationship between social structure and voting, and thus make scholars better equipped to understand modern electoral behaviour.

\section{Acknowledgments}


I would like in particular to thank Oddbjørn Knutsen, Rune Stubager, Romain Lachat, Carl Henrik Knutsen and the three anonymous reviewers for thorough and highly useful comments on previous drafts of this article. I have furthermore received useful comments from participants at the $1^{\text {st }}$ Leuven-Montréal Winter School on Elections in Leuven; the Politics Seminar at the Institute for Social Research in Oslo; as well as my colleagues at the Department of Political Science at the University of Oslo. Any remaining errors remain my responsibility.

\section{References}

Achterberg, P. and D. Houtman (2007). "Class is not dead - it has been buried alive: class voting and cultural voting in postwar western societies (1956-1990).” Politics \& Society, 35(3): 403-426.

Anderson, D. and A. Heath (2003). "Social Identities and Political Cleavages: The Role of Political Context”, Journal of the Royal Statistical Society, Series A, 166: 301-327.

Bakker, R., C. Vries, E. Edwards, L. Hooghe, S. Jolly, G. Marks, J. Polk, J. Rovny, M. Steenbergen and M. Vachudova (2015), "Measuring Party Positions in Europe: The Chapel Hill Expert Survey Trend File, 1999-2010”, Party Politics, 21(1): 143-152.

Bengtsson, M., T. Berglund, and M. Oskarson (2013). "Class and ideological orientations revisited: an exploration of class-based mechanisms." The British Journal of Sociology, 64(4), 691-716.

Bengtsson, Å., K.M. Hansen, Ó.P. Hardarson, H.M. Narud, and H. Oscarsson (2014). The Nordic Voter: Myths of exceptionalism. Essex: ECPR Press.

Benoit, K. and M. Laver (2006). Party Policy in Modern Democracies. New York: Routledge.

Butler, D.E. and D.E. Stokes (1974). Political Change in Britain: The Evolution of Electoral Choice (2 ${ }^{\text {nd }}$ ed.). London: MacMillan. 
Betz, H.G. and S. Meret (2013). "Right-wing populist parties and the working-class vote: what have you done for us lately?", chapter 4 in J. Rydgren (ed.), Class Politics and the Radical Right. New York: Routledge.

Bjørnstad, R. (2015). Rapport nr. 2-2015: Virkninger av allmenngjфring av tariffavtaler. Center for Wage Formation, FAFO and Samfunnsøkonomisk analyse AS. Accessible at https://evalueringsportalen.no/evaluering/virkninger-av-allmenngjoring-avtariffavtaler-2/R2-2015\%20Virkninger\%20av\%20allmenngj\%C3\%B8ring.pdf/@@inline [16.05.2017].

Brooks, C. and S. Svallfors (2010). "Why does class matter? Policy attitudes, mechanisms, and the case of the Nordic countries." Research in Social Stratification and Mobility, 28, 199-213.

Cambell, A., P. Converse, W. Miller, and D. Stokes (1960). The American Voter. New York: Wiley.

Coffé, H. (2013). “Gender, class, and radical right voting”, chapter 8 in Jens Rydgren (ed). Class Politics and the Radical Right. New York: Routledge.

Dietz, T., P.C. Stern, and G. A. Guagnano (1998). "Social Structural and Social Psychological Bases of Environmental Concern”. Environment and Behavior, 30(4), 450-471. Dancygier, R. and S. Walter (2015). 'Globalisation, Labor Market Risks, and Class Cleavages', in P. Beramendi, S. Häusermann, H. Kitschelt, and H. Kriesi (eds.), The Politics of Advanced Capitalism. Cambridge: Cambridge University Press.

Dolezal, M. (2010). "Exploring the Stabilization of a Political Force: The Social and Attitudinal Basis of Green Parties in the Age of Globalization”, West European Politics, $33(3), 534-552$.

Elff, M. (2009). "Social divisions, party positions, and electoral behaviour", Electoral Studies, 28(2), 297-308. 
Ennser, L. (2012). “The homogeneity of West European party families: The radical right in comparative perspective", in Party Politics, 18(2), 151-171.

Erikson, R., J.H. Goldthorpe, and L. Portocarero (1979). "Intergenerational class mobility in three Western European societies: England, France and Sweden", British Journal of Sociology, 30(4), 415-441.

Erikson, R. and J.H. Goldthorpe (1992). The Constant Flux: A Study of Class Mobility in Industrial Societies. Oxford: Oxford University Press.

Evans, G. (1993). "Class, Prospects and the Life Cycle: Explaining the Association between Class Position and Political Preferences”, Acta Sociologica, 36, 263-276.

Evans, G. (2017). "Social Class and Voting”, ch. 9 in K. Arzheimer, J. Evans, and M.S. Lewis-Beck (eds.). The Sage Handbook of Electoral Behaviour. London: SAGE.

Evans, G. and J. Tilley (2012). "How parties shape class politics: Explaining the decline of the class basis of party support”, British Journal of Political Science, 42: 137-161.

Evans, G. and J. Tilley (2017). The New Politics of Class. The Political Exclusion of the British Working Class. Oxford: Oxford University Press.

Evans, G. and N.D. De Graaf (2013) (eds.). Political Choice Matters. Explaining the Strength of Class and Religious Cleavages in Cross-National Perspective. Oxford: Oxford University Press.

EVS (2010). European Values Study 2008, $4^{\text {th }}$ wave, Integrated Dataset. GESIS Data Archive, Cologne, Germany. ZA4800 Dataset Version 2.0.0 (2010-11-30).

Doi: $10.4232 / 1.10188$.

Franklin, M.N., T.T. Mackie and H. Valen (1992). Electoral change: Responses to Evolving Social and Attitudinal Structures in Western Nations. Cambridge: Cambridge University Press. 
Gallagher, M., M. Laver, and P. Mair (2011). Representative Government in Modern Europe. Fifth edition. London: McGraw-Hill.

Gifford, R. and A. Nilsson (2014). "Personal and social factors that influence proenvironmental concern and behaviour: A review”. International Journal of Psychology, 49(3), 141-157.

Goldthorpe, J.H. and A. McKnight (2006). "The Economic Basis of Social Class", chapter 5 in S.L. Morgan, D.B. Grusky, and G.S. Fields (eds.). Mobility and Inequality: Frontiers of Research in Sociology and Economics. Stanford: Stanford University Press.

Heath, A. (2015). "Policy Representation, Social Representation and Class Voting in Britain”, British Journal of Political Science, 45: 173-193.

Heath, A. (2016). "Policy Alienation, Social Alienation and Working-Class Abstention in Britain, 1964-2010”, British Journal of Political Science (first view).

Hobolt, S.B. (2016). "The Brexit vote: a divided nation, a divided continent", Journal of European Public Policy, 23(9): 1259-1277.

Hout, M., C. Brooks and J. Manza (1995). “The Democratic Class Struggle in the United States, 1948-1992”, American Sociological Review, 60(6), 805-828.

Houtman, D. (2003). "Lipset and "Working-Class" Authoritarianism". The American Sociologist, 34(1), 85-103.

Huckfeldt, R.R. (1984). "Political loyalties and social class ties: The mechanisms of contextual influence", American Journal of Political Science, 28: 399-417.

Inglehart, R. (1997). Modernization and post-modernization: Cultural, economic and political change in 43 societies. Princeton: Princeton University Press.

Inglehart, R. and P. Norris (2016). "Trump, Brexit, and the Rise of Populism: Economic Have-Nots and the Cultural Backlash". Faculty Research Working Paper Series 16-026. Harvard Kennedy School. 
Ivarsflaten, E. (2005). “The vulnerable populist right parties: No economic realignment fuelling their electoral success." European Journal of Political Research, 44(3): 465-492.

Ivarsflaten, E. and R. Stubager (2013). "Voting for the populist radical right in Western Europe: the role of education", chapter 7 in J. Rydgren (ed), Class Politics and the Radical Right. New York: Routledge.

Jansen, G. (2011). Social Cleavages and Political Choices: Large-scale Comparisons of Social Class, Religion and Voting Behaviour in Western Democracies. Nijmegen: Ipskamp Drukkers BV.

Kitschelt, H. and P. Rehm (2014). “Occupations as a Site of Political Preference Formation“, Comparative Political Studies, 47(12), 1670-1706..

Knutsen, O. (2006). Class Voting in Western Europe - A Comparative Longitudinal Study. Lanham: Lexington Books.

Knutsen, O. (2007). "The Decline of Social Class", chapter 24 in R.J. Dalton and H. Klingemann (eds.). The Oxford Handbook of Political Behaviour. Oxford: Oxford University Press.

Knutsen, O. (2017). Social Structure, Value Orientations and Party Choice in Western Europe. Cham: Palgrave Macmillan.

Knutsen, O. and P.E. Langsæther (2016). «Class Voting in Western Europe - Do Various Class Schemas Make A Difference?” Paper presented at the IPSA World Congress, Poznan, 2016.

Knutsen, O. and E. Scarbrough (1995). "Cleavage Politics", in J.W. van Deth and E. Scarbrough (eds.). The Impact of Values. Oxford: Oxford University Press.

Langsæther, P.E. (2014). Class Voting and Value Orientations: The Fourth Generation. Master's thesis. Oslo: Reprosentralen, University of Oslo. 
Lipset, S.M. and S. Rokkan (1967). "Cleavage structure, party systems, and voter alignments: An introduction", chapter 1 in S.M. Lipset and S. Rokkan (eds.), Party Systems and voter alignments. New York: The Free Press.

Lipset, S.M. (1959/1981). Political Man: The Social Bases of Politics. Baltimore: Johns Hopkins University Press.

Mudde, C. (2007). Populist Radical Right Parties in Europe. Cambridge: Cambridge University Press.

Nieuwbeerta, P. (1995). The Democratic Class Struggle in Twenty Countries 19451990. Amsterdam: Thesis Publishers.

Oesch, D. (2006). “Coming to Grips with a Changing Class Structure: An Analysis of Employment Stratification in Britain, Germany, Sweden and Switzerland", in International Sociology, 21(2), 263-288.

Oesch, D. (2008). 'Explaining Workers' Support for Right-Wing Populist Parties in Western Europe: Evidence from Austria, Belgium, France, Norway, and Switzerland.” International Political Science Review, 29, 349-373.

Oesch, D. (2013). "The class basis of the cleavage between the New Left and the radical right: an analysis for Austria, Denmark, Norway and Switzerland”, chapter 2 in J. Rydgren (ed.), Class Politics and the Radical Right. New York: Routledge.

Oesch, D. and L. Rennwald (2018). “Electoral competition in Europe’s new tripolar political space: Class voting for the left, centre-right and radical right", European Journal of Political Research.

Oskarson, M. and M. Demker (2013). “Another kind of class voting: the workingclass sympathy for Sweden Democrats", chapter 10 in J. Rydgren, Class Politics and the Radical Right. New York: Routledge. 
Rennwald, L. and G. Evans (2014). "When Supply Creates Demand: Social Democratic Party Strategies and the Evolution of Class Voting”, West European Politics, 37 (5), 1108-1135.

Spies, D. (2013). "Explaining working-class support for extreme right parties: A party competition approach", Acta Politica, 48(3), 296-325.

Stubager, R. (2006). The Education Cleavage: New Politics in Denmark. Aarhus: Forlaget Politica.

Svallfors, S. (2006). The Moral Economy of Class: Class and Attitudes in Comparative Perspective. Stanford: Stanford University Press.

Tilley, James (2015). “'We Don’t Do God'? Religion and Party Choice in Britain”, British Journal of Political Science, 45 (4): 907-927.

Thau, M. (2017). "How Political Parties Use Group-Based Appeals: Evidence from Britain 1964-2015”, Political Studies.

Van Deth, J.W. and E. Scarbrough (1995). “The Concept of Values” in J.W. van Deth and E. Scarbrough (eds.). The Impact of Values. Oxford: Oxford University Press.

Van Liere, K.D. and R.E. Dunlap (1980). "The Social Bases of Environmental Concern: A Review of Hypotheses, Explanations and Empirical Evidence", Public Opinion Quarterly, 44(2), 181-197.

Vestin, E. and M. Oskarson (2017). "Den svenska klassröstningen på reträtt - Gör ett nytt klasschema någon skillnad?““ Politica 49(2): 179-198.

Weakliem, D.L. and A.F. Heath (1994). "Rational Choice and Class Voting", Rationality and Society, Vol. 6, No. 2: 243-270. 